\title{
O KUJÀ JORGE KAGNÃG GARCIA: O XAMANISMO, A SUA VIDA E O ESTADO DE ESPÍRITO KAINGANG'
}

ROGÉRIO REUS GONÇALVES DA ROSA²

UFPel

\begin{abstract}
RESUMO: Jorge Kagnãg Garcia é kujà (xamã) kaingang, tendo como espírito auxiliar a onça e o santo São Jorge. Trata-se de um senhor de noventa e sete anos, metade kamẽ, que vive na Terra Indígena Nonoai. Jorge é um interlocutor que traz uma notável contribuição ao pensamento etnológico. Além de inúmeras mençõesem textos, ele é protagonista nos documentários Kanhgág Ag Kãme (Histórias Kaingang), Kiki - O Ritual da Resistência Kaingang $e$ Kanhgág Kanhró (Sabedoria Kaingang), além do CD Kanhgág Jykre (Pensamento Kaingang). Além disso, esse kujà é líder espiritual do Encontro dos Kujà na aldeia Ỹmã Topẽ Pẽn, no Morro do Osso, Porto Alegre, e do Dia do Índiona Por Fi Gá, em São Leopoldo, além de organizador do Ritual do Kiki na aldeia Kondá, em Chapecó, e mestre indígena do projeto Saberes Indígenas na Escola (SECADI/MEC).
\end{abstract}

PALAVRAS-CHAVE: Kaingang; Jorge Kagnãg Garcia; xamanismo.

ABSTRACT: Jorge Kagnãg Garcia is a kujà (a shaman) kaingang, whose auxiliary spirits are the jaguar and the saint São Jorge. He is a 97 years old man, who belongs to the kamẽ half, and lives in Terra Indigena Nonoai. Jorge is a speaker with a remarkable contribution to ethnological thought. Apart from being mentioned intexts countless times, he is the protagonist of the following documentaries: Kanhgág Ag Kãme (Kaingang Stories), Kiki - The Ritual of Kaingang Resistence and Kanhgág Kanhró (Kaingang Wisdom), and, also, of the CD Kanhgág Jykre (Kaingang Thought). Furthermore, he is the spiritual leader of the Meeting of the Kujà, in the Ỹmã Topẽ Pẽn village, in Morro do Osso, Porto Alegre, and of the Dia do Índio, in Por Fi Gá, São Leopoldo. Jorge is, besides all that, the organiser of the Kiki Ritual in Konda village, in Chapecó, and the indigenous master of the governmental project Saberes Indigenas na Escola.

\footnotetext{
${ }^{1}$ A ideia deste texto originou-se a partir do aceite do resumo Kujà Jorge Kagnãg Garcia: Sa vie, le chamanisme kaingang et l'utilisation des nouvelles technologies pour les anciens amérindiens (junto com o documentário Kanhgág Kanhró / Sabedoria Kaingang) no Grupo de Trabalho "Éprouver le Religieux en Milieu Autochtone: Vers de Nouvelles Méthodes", coordenado por Robert R. Crépeau (Université de Montréal, Canadá) e Frédéric Laugrand (Université Laval, Canadá), durante a 33ème Conférence de la ISSR Société Internationale de Sociologie des Religions, na cidade de Louvain-la-Neuve, Bélgica, em 4 de julho de 2015. O gentil convite de Maria Paula Prates, Luiz Fernando Caldas Fagundes e Sergio Baptista da Silva para a publicação de um artigo justamente sobre essa pessoa kaingang veio ao encontro de minha expectativa de homenagear seu Jorge e sua excepcional contribuição à etnologia ameríndia. Aproveito a oportunidade para manifestar minha gratidão a todos/as por essa oportunidade. Eu agradeço em especial a Robert Crépeau pela leitura e pelos comentários ao texto.

2 Etnólogo, professor do Bacharelado em Antropologia e do Programa de Pós-Graduação em Antropologia (PPGAnt) e Coordenador do Núcleo de Etnologia Ameríndia (NETA), vinculados à Universidade Federal de Pelotas (UFPel). E-mail: rosa.rogeriogoncalves@uol.com.br .
} 
KEYWORDS: Kaingang; Jorge Kagnãg Garcia; shamanism.

\section{Introdução}

Na memória de minha origem na etnologia ameríndia, em outubro de 1991, eu então com vinte e seis anos de idade, conheci os Kaingang de Iraí no América Latina, Hacer Nuestra La Integracion, um evento sobre os quinhentos anos de invasão da América Latina pela Europa, ocorrido em San Javier, província de Misiones, Argentina, durante uma apresentação da peça $A$ Dança da Conquista, da tribo de atuadores Ói Nóis Aqui Traveiz, de Porto Alegre.

Desse tempo para cá, convivi com muitos Kaingang em aldeias e cidades, nas mais diversas situações. Muitas dessas pessoas - Augusto Opé da Silva, Valdemar Vicente, Jair Sales, Luis Salvador (Saci), Vicente Fernandes Fokanh, Chiquinho da Silva, Chapecozinho, Irineu Xarimbang, José Gabriel Kapir, Diogo Pica Pau, Silvano, Simplício Waktun, Danilo Braga, Jorge Kagnãg Garcia, Maria Constante Garcia, Pedro Pó Mág Garcia, Dorvalino Refej Cardoso, Luisa Jagnĩgri Pedroso, Kasu Kajẽró, Zílio Jagtyg Salvador, Zaqueu Key Claudino, Pedro Sales - marcaram minha vida pessoal e profissional, sobretudo os homens e, particularmente, os mais velhos. Um deles, em outubro de 2013, durante o II Seminário Internacional de Educação Indígena 3 e o "Encontro Com a Religiosidade Indígena" 4 , realizados na Universidade Federal de Santa Maria (UFSM), disse sentir-se como meu "avô". O nome dele é Jorge Kagnãg Garcia. É dessa pessoa kaingang que tratarei nesse artigo.

Jorge Kagnãg Garcia é Kaingang5, kujà (xamã) desse coletivo, metade kamẽ, profundo conhecedor da floresta, além de mestre do

\footnotetext{
${ }^{3}$ Realizado pelo Programa de Educação Tutorial (PET) Indígena, coordenado pela Prof ${ }^{\mathrm{a}}$. Ceres Karam Brum.

${ }^{4}$ Realizado pelo AFIRME - Observatório de Ações Afirmativas, coordenado pela Ana Lucia Aguiar Melo.

${ }^{5}$ Cabe dizer que os Kaingang, vocábulo que nomeia "gente do mato", são parte das Sociedades Jê Meridionais, ligados ao tronco linguistico Macro-Jê. Eles estão entre os quatro povos ameríndios mais populosos do Brasil, com cerca de quarenta e cinco mil pessoas. A maioria dos Kaingang está concentrada em terras indígenas reconhecidas pela Fundação Nacional do Índio (Funai) nos estados de São Paulo, Paraná, Santa Catarina e Rio Grande do Sul, sendo que, nas últimas décadas, tem se intensificado a presença dessas pessoas configurando aldeias nos bairros suburbanos e na zona rural dos
} 
projeto Saberes Indígenas na Escola (SECADI/MEC) na Universidade Federal do Rio Grande do Sul (UFRGS) ${ }^{6}$. No xamanismo kaingang, esse kujà tem a parceria da jagrẽ, espírito auxiliar onça e o santo São Jorge (ROSA, 2005). Trata-se de um senhor de noventa e sete anos de idade, casado com Maria Constante Garcia, metade kanhru, pai de onze filhos, avô de dezenas de netos, bisnetos e tetranetos. O casal vive no setor Capão Alto da Terra Indígena Nonoai, no estado do Rio Grande do Sul (RS).

Ele é ágrafo, poliglota, um exímio narrador das aventuras dos "bichinhos" e de seus espíritos, donos da floresta. Trata-se de um interlocutor que traz uma notável contribuição ao pensamento etnológico contemporâneo. Além de ter seus conhecimentos citados em trabalhos acadêmicos de projeção nacional e internacional (ROSA, 2005; 2014a e 2014b; NASCIMENTO, 2010; CRÉPEAU, 2012 e 2015; CRÉPEAU e ROSA, no prelo; JACODSEN, 2013; PINHEIRO, 2013; MARÉCHAL, 2015), perícias e relatórios (ROSA, 2000; FREITAS, 2000; 2007), Jorge Kagnãg Garcia também é protagonista nos documentários Kanhgág Ag Kãme (Histórias Kaingang, de 2000); Kiki - O Ritual da Resistência Kaingang, de 2014, e Kanhgág Kanhró (Sabedoria Kaingang, de 2015), além de registrar sua marcante voz no CD Kanhgág Jykre (Pensamento Kaingang, de 2002). Visando a fortalecer as práticas culturais, espirituais e políticas pela demarcação e homologação das terras indígenas para os Kaingang, esse kujà é o líder espiritual dos eventos Encontro dos Kujà, organizado pelos Kaingang na aldeia Ỹmã Topẽ Pẽn, no Morro do Osso, Porto Alegre, realizado desde 2006; e Dia do Índio, na Por Fi Gá, São Leopoldo, efetuado em 2017. Além disso, é o principal organizador do ritual do Kiki, executado na aldeia Kondá, Chapecó, em 2011, cujo "dono" foi o seu neto e professor bilíngue Jocemar Kóvenh Garcia.

Antes de se avançar neste texto biográfico sobre Jorge Kagnãg Garcia, realizarei uma incursão pela discussão etnológica sobre xamanismo em outras partes do mundo e entre os Kaingang. Com isso à frente, o/a leitor/a perceberá a sensibilidade dos conhecimentos e da vida dessa pessoa kaingang.

municípios do sudeste e sul do Brasil, além de parques florestais e estradas rodoviárias que atravessam as principais cidades regionais.

${ }^{6}$ Projeto coordenado pela Prof ${ }^{\mathrm{a}}$. Maria Aparecida Bergamaschi e Prof ${ }^{\mathrm{a}}$. Magali Mendes Menezes. 


\section{O xamanismo em outras partes do mundo e entre os Kaingang}

A partir da etnologia ameríndia, o xamanismo é definido enquanto "sistema social", "sistema cosmológico", "complexo xamânico" e "sistema de pensamento complexo". Quer dizer, reportando-se à experiência dos coletivos ameríndios nas terras baixas, Jean Langdon demarca essa manifestação como uma instituição social duradoura, que expressa as preocupações máximas de uma sociedade e que, portanto, deve ser compreendida holisticamente (LANGDON, 1996, p. 28-30; CHAUMEIL, 2000; CRÉPEAU, 1988a e 1988b).

Da mesma forma, Jean-Pierre Chaumeil e Robert R. Crépeau tratam esse complexo xamânico enquanto uma instituição social, na medida em que o xamanismo dá movimento aos aspectos que constituem as relações entre humanos e espíritos, nos quais se encontram vinculados os ameríndios (CRÉPEAU, 1988a; CHAUMEIL, 2000). Tendo em vista esse ponto, segundo Crépeau:

[...] compreender o xamanismo é de início apanhá-lo do interior, quer dizer do ponto de vista dos próprios xamãs e de seus grupos, da lógica subjacente à prática ou a isto que poderíamos chamar de fundamentos dessa instituição (CRÉPEAU, 1988a, p. 02).

A expressão "xamã" origina-se de um empréstimo da língua toungouse, do nordeste siberiano, etimologicamente ligada à ideia de movimento e agitação. Na prática, essa pessoa gesticula, berra, pula, canta, estremece, cai inerte em busca da mediação entre o mundo humano e o mundo dos espíritos. O resultado do seu trabalho é julgado pelas pessoas de acordo com o bem-estar alcançado. De forma permanente, essa chefia necessita provar ao seu coletivo o poder que exerce sobre os espíritos e o controle sobre os fatores incertos da aparição das presas durante a caça (LANGDON, 1996; PERRIN, 1988; CRÉPEAU, 1988a e 1988b; CHAUMEIL, 2000; HAMAYON, 2011).

Segundo Michel Perrin, "o xamanismo é uma constante 'atualização' do mundo mítico" (1978, p. 208). As pessoas se sentem doentes porque seus espíritos foram raptados pelos espíritos 
pertencentes a outros mundos e, sendo assim, é nesse plano que o xamã, contando com a ajuda do seu guia, terá que trabalhar para reverter essa situação que mexe com os sentimentos das pessoas.

Como um profissional, todo xamã tem apoio de espíritos auxiliares, que lhe servem como emissários e mediadores dos conflitos entre humanos e não humanos. Esses guias são visíveis (ou não) somente aos xamãs e aos pares consentidos. Segundo Alfredo Tomasini (1992), praticamente todos os animais apresentam uma espécie de duplo, sendo essa característica típica da instituição xamânica, isto é, o fato que possibilita aos animais o ingresso à condição de espíritos auxiliares dessas chefias. No que diz respeito à quantidade de guias para cada xamã, essa grandeza muda de cultura a cultura, contexto a contexto e biografia a biografia.

Outro princípio que se atravessa no convívio de xamãs e espíritos auxiliares é o "travestismo ritual". Trata-se de uma mútua possibilidade de mudança desses dois seres, em que os xamãs, através de sonhos ou rituais, adotam as maneiras e a roupagem de outro gênero humano, de algum animal, ou até mesmo assumem as formas invisíveis dos espíritos, da mesma maneira que os espíritos auxiliares tomam a forma humana e de certos animais (LANGDON, 1996; HAMAYON, 2011).

Em particular, entre os Kaingang, o xamã recebe o nome de kujà, sendo o mesmo traduzido para o português como "curandor" e "pajé" (palavra de origem tupi-guarani). Esse profissional tem como seu parceiro o jagrẽ, que assume tanto a forma não humana como humana: espírito animal da floresta (por exemplo, jaguatirica, gavião e coruja), espírito vegetal da floresta (taquara, árvore e cacique das matas), espírito da água (espírito água da floresta e água santa), santo do panteão do catolicismo popular (Nossa Senhora Aparecida, Santo Antônio e São João Maria). O trabalho do jagrẽ junto a um kujà pode acontecer de forma individual ou partilhada. Por exemplo: os jagrẽ de Luisa Jagnĩgri Pedroso (também chamada de Luisa Marcolino) são os seguintes: leãozinho, tigre, Jesus Cristo, Ave Maria, Nossa Senhora Aparecida e Santa Catarina (ROSA, 2005).

No xamanismo kaingang, em se tratando da relação kujà e jagrẽ e das metades kamẽ e kanhru, o jagrẽ tem sua "marca" associada à mesma metade do kujà (CRÉPEAU, 2007). Nesse caso, a relação peculiar que liga 
esses dois seres de mesma marca - kujà e jagrẽ com metades kamẽ/kamẽ ou kanhru/kanhru - inverte a regra sociológica kaingang, na qual um kamẽ desposa um kanhru (e vice-versa).

Tratando-se da iniciação, a formação de um kujà é marcada por dois momentos: na primeira fase, trata-se da relação de um experiente kujà com um neófito no domínio "casa" e "espaço limpo"; na segunda fase, mais decisiva, trata-se do encontro do aprendiz com seu jagrẽ, dessa vez no domínio "floresta virgem" (ROSA, 2005).

A relação de um kujà com o neófito no domínio casa e espaço limpo trata-se de um acontecimento coletivo, visível à sua rede de parentesco. Segundo comentários de Jorge Kagnãg Garcia, quando um kujà organiza um ritual de nominação das crianças, ele convida outros xamãs para participar desse evento. A partir da reunião desses indivíduos, por exemplo, em um ritual do Kiki, eles decidem, de início, em quais crianças eles investirão os seus conhecimentos; logo, a busca de remédios do mato na floresta; a seguir, a preparação destes com "água limpa" no espaço limpo; na continuidade, a separação dos remédios em recipientes conforme a formação de cada criança e, por fim, o pedido de autorização aos pais para banhar e para transformar os seus filhos em um kujà, caçador ou melador.

A segunda fase de formação do neófito trata-se de um acontecimento reservado. Esse momento tem início quando o velho kujà intima o seu aprendiz a partir sozinho para a floresta para ele se encontrar pela primeira vez com seu jagrẽ. Importante destacar que, nesse processo de formação na floresta, não é o kujà que elege o seu jagrẽ, mas o inverso. A partir desse momento, todo kujà neófito trabalhará associado a seu espírito auxiliar, acessando o seu conhecimento através de sonhos tanto na floresta quanto em casa. Embora a experiência onírica seja valorizada por todos Kaingang, o kujà é o único que tem acesso a tais visões e diálogos de modo voluntário (ROSA, 2005).

Além disso, essa relação de poder é marcada por um vínculo matrimonial. A kujá Lurdes Nimpré da Silva, ligada à aldeia Por Fi Gá, possui dois jagrẽ aves. Eles são masculinos porque "uma kujà mulher tem guia masculino". O falecido rezador do Kiki, Simplício Waktun, tinha como guia a Maria da Erva, descrita por ele como uma "linda mulher". 
Esse casamento ocorre na floresta quando o parceiro espiritual introduz no corpo do xamã, sobre cada axila ou em seu peito, pequenas sementes de nome kaáfei, que confirmam o estabelecimento do vínculo matrimonial entre os dois. Essa aliança também acontece através da mistura de gotas de sangue (CRÉPEAU, 1997; ROSA, 2011).

O caso da kujà Luisa Jagnĩgri Pedroso ter como guias o leãozinho, tigre, Jesus Cristo, Ave Maria, Nossa Senhora Aparecida e Santa Catarina revela que o xamanismo kaingang, enquanto instituição social, está atravessado por dois sistemas ideológicos sobrepostos, que constituem uma unidade: o "sistema kujä" e o "sistema caboclo", respectivamente. A partir da lógica do saber guiado, no sistema kujà a ênfase do xamanismo está colocada no trabalho de mediação do kujà a partir do domínio floresta virgem, vinculado ao poder do jagrẽ animal ou vegetal, à língua kaingang e ao prestígio da floresta enquanto sua instituição paradigmática. Embora haja jagrẽ vegetais, a grande ênfase do xamanismo kaingang é em torno dos jagrẽ animais do "matão". Por sua vez, no sistema caboclo, o destaque está no trabalho do curandor kaingang ou caboclo, a partir do domínio casa e espaço limpo, vinculados ao poder dos santos ligados ao panteão do catolicismo popular, à língua portuguesa e à influência das instituições altarzinho e igrejinha de tabuinhas (ROSA, 2005 e 2014a).

A contiguidade dos dois sistemas aparece, ainda, nas seguintes características dessa instituição: o uso de remédio do mato; a presença do saber guiado, característica chave de uma relação xamânica; o poder de cura é cedido pelo espírito auxiliar ao kujà ou curandor; as curas são realizadas pelo kujà ou curandor a partir de sonhos e práticas profiláticas; a importância do poder de adivinhação do kujà ou curandor; o fato de os pacientes deverem se dirigir à casa do kujà ou curandor para receber o tratamento adequado; e, até o presente, o aspecto de a grande maioria de kujà ou curandor ser ágrafa (ROSA, 2005).

Apesar da drástica diminuição da formação arbórea nas terras indígenas, sua gradual substituição pelo arrendamento e lavouras de soja (Glycine max), além do desaparecimento da fauna, flora e espíritos, todos associados ao Bioma Mata Atlântica, saliento que o sistema kujà perdura na vida dos Kaingang. Sobrepondo a floresta pelo espaço limpo 
ou pela casa, o espírito da onça pelo santo do panteão do catolicismo popular, traduzindo kujà por curandor, o sistema caboclo replica a lógica do sistema kujà - cuja matriz é a floresta - no xamanismo kaingang (ROSA, 2005 e 2014a).

É possível dizer que o sistema kujà e o sistema caboclo são partes do pensamento mitológico kaingang, a primeira apontando para a intriga e o trabalho do sobre-humano kujà com o não humano jagrẽ pelo bem-estar espiritual/físico dos Kaingang, e a segunda encaixando nesse acontecimento o curandor caboclo e brasileiro junto com seus altarzinhos, igrejinhas de tabuinhas, capelinhas, mastros de bandeiras e cruzes de cedro, além dos santos que caminham pela terra e o encontro com os descendentes europeus (ROSA, 2005 e 2014a).

Embora não seja mais a prática dominante nas terras indígenas e nas cidades onde vivem os Kaingang, o trabalho de um kujà constitui uma dimensão importante, sendo, internamente, um ponto de vista concorrente a outras visões de mundo, ligadas ao evangelismo e ao pentecostalismo. Do ponto de vista etnológico, segundo Crépeau, não há uma ruptura entre xamanismo e pentecostalismo, na medida em que o segundo é a "faceta de um único modo explicativo da persistência do xamanismo"7 (2012, p. 304).

No próximo tópico, explicitarei ainda mais o xamanismo kaingang, dessa vez incluindo aspectos da biografia do kujà Jorge Kagnãg Garcia.

\section{O kujà Jorge Kagnãg Garcia: genealogia e concepções xamânicas}

Jorge Kagnãg Garcia é uma pessoa gentil: ele vive com sua família na Terra Indígena Nonoai. Trata-se de um homem que possui o dom da oralidade. Quando esse homem puxa a cadeira e começa a narrar sobre o "matão", uma floresta repleta de jaguatiricas, macacos, tatus, corujas

\footnotetext{
${ }^{7}$ Para Crépeau, "enquanto o xamanismo implicaria aos seus adeptos uma continuidade com a época da vida na floresta, o modo de vida dos velhos e das forças da natureza, as religiões evangélicas pressuporiam uma saída frente ao avanço gradual da vida moderna sobre seus pequenos espaços, além dos problemas sociais e individuais que se colocam, por exemplo, corrupção, desemprego, violência conjugal, jogo e alcoolismo. Esta relação deve ser pensada enquanto da dinâmica religiosa kaingang ligada a uma problemática identitária, frente a um conflito de memória e a uma falta de reconhecimento de parte da população nacional e das elites regionais" (2012, p. 326).
} 
e urubus reocupa os pensamentos de sua atenta plateia. Esse kujà é agrafo e poliglota, pois fala kaingang e português, além de compreender o guarani.

Jorge Kagnãg Garcia é filho de João Valencio Garcia e Margarida de Paula. Em uma das viagens dos pais aos parentes do Xapecozinho (Santa Catarina), a sua mãe veio a falecer. Margarida de Paula foi sepultada no cemitério dos Guarani dessa aldeia. João Valencio Garcia casou-se, então, com uma filha do cacique kaingang Kỹnója ${ }^{8}$, ainda na época do toldo Votouro.

Margarida de Paula era descendente de Guarani, e João Valencio Garcia, de Guarani e caboclo. Ou seja, Jorge Kagnãg Garcia, um dos mais prestigiados kujà kaingang, é filho de pais Guarani. Conforme seu comentário: "eu me criei com Kaingang Coroado, aprendi a falar o idioma coroado [kaingang]. Quando criança, falava idioma guarani, depois mudei. Os que me criaram me ensinaram. Minha raça mesma era Guarani".

Jorge Kagnãg Garcia trabalha com a jagrẽ onça e o São Jorge. Diferente de outros kujà que possuem jagrẽ de mesma metade, para esse xamã, a marca replica a regra sociológica kaingang, na qual um kujà de uma metade terá um jagrẽ de metade oposta. Em suas palavras, "se a kujà é kamẽ, ele é kanhru. Tudo é com os jãmré [cunhados]". Assim, Jorge pertence à metade kamẽ, e seus jagrẽ, à metade kanhru.

Tratando-se da sua formação enquanto xamã, o kujà responsável foi o pai de sua esposa, Maria Constante Garcia, nas duas fases assinaladas no tópico acima. Eis o relato de Jorge Kagnãg Garcia acerca da experiência relacionada à floresta e à revelação de sua jagrẽ, então aos vinte e cinco anos de idade:

O finado sogro foi que me preparou. Quando ele viu que eu estava no ponto de sabedoria, ele me disse: "você vai hoje no mato e derruba um coqueiro, tira aquele bojão [espata do coqueiro] dele que é da flor, que não nasceu a flor ainda, então aquele bojão está a flor dentro, você corta aquela cachopa, atore ela um tanto assim, depois arranque a flor dela do meio e encha de remédio de tudo quanto é folha, a folha que você puder botar dentro encha bem cheio, bote água e deixe lá no mato". Eu fui e fiz aquilo lá. Ele mandou.

\footnotetext{
${ }^{8}$ Lê-se "Candóia".
} 
Dali nove dias ele me mandou: "agora você vai lá e vê, se tiver seco, se não tiver nada d'água, você botou bastante água, se não tiver mais água, você corta um pouquinho da tua pele que saia duas, três gotas de sangue e pingue dentro daquele remédio e encha d'água e bota lá de novo". Mais nove dias, ele me mandou lá para mim beber: "está quase pronto!". Me aconselhou, era para eu ter bastante coragem, nada ia acontecer comigo: "agora você vai lá no mato e tire toda tua roupa e deita perto daquele bojão de remédio, enche d'água, ali no escurecer, no raio da noite, quando estiver cerrada a noite, vai vir um bicho. Só não tenha medo que ele não vai te fazer nada, ele só vai vir te ver, vai fazer uma visita pra você. Não leve nada, não leve nem uma faca". Eu fui. Cheguei lá, quando ficou bem escuro tirei toda a roupa e deitei. Deitado no chão a gente vê o barulho de longe, eu vi aquele [som] na folha seca tac tac tac... E eu deitado de barriga pra cima. Veio com dois paus assim e parou, eu só vi aquele pretão [a onça] por cima de mim e pulou pra cá, de lá ele pulou de volta sobre mim, lá ele deu três pulos e caiu de novo pra cá e aquietou ali. Daí eu tava picado de pernilongo e eu não podia me mexer porque estava louco de medo, se eu me mexo ele pega. Ele disse que não era para ter medo, que ele não fazia mal, eu não vi para onde ele foi, me levantei e vesti a roupa ligeiro, acendi umas taquaras e levei aquele bojão, ele me disse que era para eu levar. "O que você viu lá?" Eu vi um bicho grande pulando sobre mim, só que era escuro eu não vi o que era, ele pulava sobre mim. Ele deu uma risadinha: "ah, aquela é a onça!". Ela nunca deixou de me perseguir quando ia no mato. É o espírito dela. Quando faleceu [o kujà Pedro Constante], ficou eu no lugar dele.

Muito se tem a pensar sobre essa narrativa. Inicialmente, nem todos os Kaingang superam a barreira de passar uma noite na floresta, nu e à espera do jagrẽ. O professor bilíngue Dorvalino Refej Cardoso queria ser kujà: ele passou pela primeira fase de formação, mas, quando seu mestre solicitou que se dirigisse para o mato, ele não se sentiu com disposição para transpor tal desafio.

Porém, algumas pessoas não passam por essa experiência para se tornarem uma kujà. Pedro Pó Mág Garcia, filho de Jorge Kagnãg Garcia, metade kamẽ, com cerca de cinquenta anos, teve a seguinte formação xamânica: um dia, ele foi ao mato rezar, e apareceram duas aves: o martim da água (Martim-pescador, família A/cedinídeos) e a pomba-rola 
(pomba-amargosa, família Columba plumbea). Suas jagrẽ aves são de metade oposta à sua, portanto, kanhru. Desde cedo, Jorge Kagnãg Garcia pensava que Pedro Pó Mág Garcia tinha poder para ser um kujà porque, quando ele ia ao mato Campina Grande, na Terra Indígena Nonoai, diferentemente dos demais filhos, aconteciam aparições de espíritos de pessoas, sons e uivos de animais. Pedro acrescenta, ainda, um novo dado à sua formação: ele atribui a sua iniciação ao avô materno, Pedro Constante.

Voltando a Jorge Kagnãg Garcia: ele se relaciona com a floresta, domínio paradigmático da atividade xamânica, testando os seus fundamentos teóricos e metodológicos - comparando-se, por exemplo, ao que faz um primata nesse território:

O macaco é inteligente. Lá na mata ele é o dono. Como eu, porque eu aprendi muitas coisas diferencial na mata? É porque eu tive paciência de notar o quê que está acontecendo, qualquer barulho que eu via no mato eu ia lá ver o quê que era. Às vezes dava um gemido, parecia uma pessoa, eu ia lá ver o que é aquilo, até que vai indo que descobre o quê que faz aquele barulho. Não é torcer pra gente, o que não é para o dom da pessoa, você vai no mato não faz conta de nada, você vai atrás daquilo que você foi, você vai caçar, vai procurar os bichinhos pra matar.

Com relação ao casamento mítico apontado pela etnologia enquanto uma característica do xamanismo, quando eu interrogo Jorge Kagnãg Garcia sobre seu vínculo matrimonial e sentimento de posse de sua jagrẽ, ele sorri, desconversa, mostra-se incrédulo acerca desse dado no trabalho de outros kujà. Para Hamayon (2011), há uma estreita relação entre a ideia de aliança com um espírito e o desejo de atrair a sorte, a fortuna, em uma caça na floresta.

A etnologia kaingang aponta que, nessa "lógica de aliança" (HAMAYON, 2011), a relação kujà e jagrẽ é marcada por ciúmes e disputas com o cônjuge humano desse xamã. Diga-se de passagem, essa união nem sempre é tolerada por tal espírito auxiliar. Acerca disso, a kujà Lurdes Nimpré da Silva me disse que há dois tipos de jagrẽ: aqueles que consentem a união carnal dos kujà com um parceiro humano e aqueles que não aprovam esse tipo de compromisso. Esse 
segundo jagrẽ é chamado por ela de "guia de ferro". Um bom exemplo dessa situação é o da falecida Sebastiana, que dormia três noites com seu cônjuge humano e as demais com seu jagrẽ (ROSA, 2011).

Partindo desse pressuposto, a jagrẽ de Jorge Kagnãg Garcia dá a entender que consente a relação dele com sua parceira humana, Maria Constante Garcia. Mas, essa relação matrimonial construída há décadas, marcada pela contínua presença de filhos, netos e bisnetos em sua moradia, já passou por momentos difíceis. Inclusive, certa vez, Maria separou-se de Jorge porque reparou, durante uma caminhada pela floresta, que a felina seguia os passos do seu marido.

Eu aprendi com Jorge Kagnãg Garcia que um kujà não é igual a outro devido à influência das diferentes espécies de jagrẽ e a qualidade de poder que elas cedem aos kujà. Inclusive, um kujà é mais (ou menos) poderoso que seu colega de acordo com o tipo de jagrẽ que o orienta. Por conta disso, talvez seja possível explicar porque os kujà são pessoas idiossincráticas, de grande singularidade. Todos eles têm sólida autoestima, manifestando-se mais capacitados que um colega na cura das pessoas (ROSA, 2014b).

Em meu texto Os Kujà São Diferentes?... (ROSA, 2014b), menciono que o grau de rivalidade de um kujà em relação a outro pode ser medido a partir de um comentário casual, uma crítica velada ou até um julgamento explícito. Meus dados inclusive apontam que Jorge Kagnãg Garcia tem como inimiga preferencial a kujà Luisa Jagnĩgri Pedroso. Por exemplo, quando eu o indaguei se acreditava no trabalho de Luisa, ele me disse de modo enfático:

- Jorge: "Nunca acreditei, achava o trabalho dela muito diferente dos antigos."

- Autor: "Diferente?"

- Jorge: "Ela trabalhava com o Negrinho do Pastoreio, aquilo é só pro mal, no meu entendimento. A Marcolina, aquela trabalha com espírito que não é legal, eu nunca acreditei nela. Em festa dela eu nunca fui, e ela nunca me convidou mesmo. Eu não gosto do trabalho dela."

A crítica de Jorge Kagnãg Garcia a Luisa Jagnĩgri Pedroso está na ordem da oralidade. Mas, há situações em que o conflito entre kujà e jagrẽ pode chegar a lesões corporais. Em janeiro de 2015, durante uma 
Rosa - O kujà Jorge Kagnãg Garcia: o xamanismo, a sua vida e o estado de espírito kaingang...

conversa a partir da escuta do CD Kanhgág Jykre e dos documentários Kanhgág Ag Kãme, Kiki - O Ritual da Resistência Kaingang e Kanhgág Kanhró, Pedro Pó Mág Garcia, que ouvia atentamente minhas conversas com Jorge, solicitou a seu pai que ele me narrasse o combate entre dois kujà. Então, Jorge tomou a palavra:

Um índio veio lá da Serrinha [Terra Indígena] e pegou a mulher do outro, ela tinha uma criancinha mamando, e ele veio a Nonoai e pegou a mulher, logrou o marido dela e levou para Guarita. Diz que o marido da mulher vivia chorando o fato da mulher e do filho, ele queria bem a criança, e daí o jãmré [cunhado] dele diz: "você nunca vai esquecer dela. Se você não judia [machucar] ela, você vai criar ela e o filho sem acontecer nada, eu vou buscar ela para ti". Ele levou ela para Guarita, naquele tempo era tudo mato. Ele disse: "não, eu cuido dela, não faço nada pra ela, trazendo ela pra mim, e a criança". Ele fez aquele plano, se aprontou e foi sozinho, um rapaz de muita coragem, buscar a irmã. Chegou lá na Guarita, se apresentou para os pã'行 dele, os $p e j^{10}$ e o outro kujà, contou a história pra ele. O cara [raptor] muito sentido, "a minha irmã, eu vim buscar ela", ele entrou de acordo, ela entrou meio roubada, pode levar. Ele mandou chamar o cara. Eles se aprontaram lá e vieram, quando chegaram no Rio da Várzea, era bem tardezinha, o rio tinha bastante água:"eu vou levar a criança para o lado de lá, deixo lá, depois eu venho te buscar". Pegou a criança botou nas costas, passou nadando. Chegou lá, botou a criança, para ela não andar atou ela num cipozinho, ela ficou chorando. Ele se jogou na água, foi buscar a irmã dele. Quando chegaram lá, uma onça tinha levado a criança, aí ficaram os dois desesperados, sem saber o que fazer. Daí anoiteceu, ele fez um ranchinho de folha de taquara. E água assim, o tempo se aprontando para a chuva, ele fez um foguinho embaixo, se deitaram embaixo, sentidos porque a criança o bicho levou. Eles, tarde da noite, ali pela madrugada, a onça veio e pulou em cima da casinha e derrubou em cima deles, passava a mão, queria pegar, e ele tinha uma faquinha, foi devagarzinho puxando aquela faquinha e a onça procurando a cabeça dele, uma folha da taquara, até

\footnotetext{
${ }^{9}$ A partir da conexão do cargo de liderança a uma categoria ritual, o trabalho do pã 'í diz respeito ao cerimonial e ao político (ROSA, 2005).

${ }^{10}$ Segundo Pedro Retón Candido: "O pej é o rezador nos velórios, uma das pessoas mais respeitadas no Posto Indígena. É ele quem pode vestir o morto, levá-lo até o cemitério e enterrá-lo. Somente o pej pode encostar no morto, pois se outra pessoa o fizer, morrerá. O pej também faz as marcas, como o kamé e o kairukre, e então as pessoas podem obedecer a acompanhar o velório" (apud VYJKÁG, 1997, p. 130).
} 
que ele viu, tava batendo o coração, tacou a faca, ela deu aquele berro e caiu. Mas ele se machucou bastante, e ela diz que não, ela tava meio por baixo dele. Clareou o dia, ele disse: "eu fico aqui e você vai avisar lá que sumiu a criança e que venham prontos que a onça está morta, mas tem a companheira dele, a fêmea, vamos matar os dois". Ele ficou lá esperando, ele estava todo machucado, até que a onça veio e pegou ele. Enquanto ela foi avisar o povo, aí eles vieram, ela voltou com eles lá, quando chegaram lá ele estava morto, a onça tinha chupado o sangue dele. Daí já foram prontos, armados todos com lanças e flechas, daí começaram a arremedar ela, embrabaram ela bem, com uns canos de taquara que fazia um berro igual a ela, começaram a fazer aqueles barulhão. Ela veio, e já deixaram gente por longe, pro lado que ela vinha, ela veio braba, não atendia pra nada, a onça, eles atacaram de flecha, mataram os dois. Daí, diz que pegaram o rapaz que estava morto, pegaram ele e levaram. Então, essa história aconteceu. Naquelas épocas, o kujà de lá, de Guarita, foi o que fez aquilo lá, ele não queria, mas como o irmão veio buscar a irmã, ele entregou. Lá, diz que pressionaram ele, fez um trabalho lá, fez um trabalho das onças matarem o irmão. Isso é conhecimento de kujà. Então um jogava com o outro, o poder deles. Isso aconteceu no Rio da Várzea, essa história foi muito falada. Outra história, eles brigavam muito com os Xokleng. Naquelas épocas eles vinham pra se vingar, matar os kujá, eles mandavam uma turma de três, quatro pessoas lá de longe, mato afora, chegavam e começavam a rondar, aqui no Rio da Várzea, o Kasu conta essa história do Chico Kajẽró, vieram para matar o Chico Kajẽró, desconfiaram, estavam rodeando eles, até que mataram aquele que veio para matar. O jãmré [Kasu Kajẽró] conta melhor essa história. Quando estavam de noite vindo para matá-lo, já estavam esperando, devoraram, mataram quatro pessoas. Tudo isto acontecia, briga de índio com índio, tudo mandado pelos kujà."

Pedro Pó Mág Garcia complementou essa narrativa afirmando que, quando um kujà mata o jagrẽ de outro kujà, esse não resiste e também vai a óbito. Esse saber relacionado à caça e à guerra entre kujà foi explicitado por Jorge Kagnãg Garcia após a escuta do canto da kujà Luisa Jagnĩgri Pedroso com seu leãozinho, registrado no CD Kanhgág Jykre. 
Outro aspecto da relação do kujà com sua jagrẽ, a partir da experiência de Jorge Kagnãg Garcia com sua onça, é que o primeiro depende da segunda para entrar na mata, para caçar um animal cedido por ela, além do acesso ao conhecimento e à localização do remédio vegetal no mato. A transmissão desse saber, que envolve pedido e cessão de poder, acontece através de sonhos, tanto na floresta quanto em casa. Retomo as suas palavras:

Se eu quero falar com qualquer mestre desses bichos, eu vou no mato e peço na sabedoria dele, eu quero que ele me explique alguma coisa do poder dele. Eu vou lá no mato, me esfrego bem de remédio, aquele remédio deles, pois cada um tem um tipo de remédio para fazer cura. Então, eu falo com ele, para ter uma experiência dele. Então, eu sonho com eles. Posso até sonhar que estou proseando com uma criança. Ele não vai representar ele, ele representa outra, pode representar às vezes um velho, senão igual a um branco, igual a um não índio, me explicando aquela pergunta que eu fiz. Ele tem muitos tipos de se apresentar pra mim. Ele vê se eu sou um kujà legal ou não, se eu acredito. Às vezes, eu proseio com uma pessoa que nem lembro dele, no sonho eu proseio com ele, uma pessoa que eu nem conheço, mas eu estou proseando com o kujà daquele que eu pedi. Ele que me mandou aquela visão falar comigo para mim entender o quê que ele tem no mandato dele. Assim que funciona nosso trabalho de kujà.

A característica do travestismo ritual, ou "mudança de roupa", também se atribui aos Kaingang do sul do Brasil, princípio esse que remete a pensar nos Buriat, povo mongol estabelecido ao redor do lago Baikal, na Sibéria Central, e nos Inuit, coletivos que vivem na região Ártica da América do Norte (HAMAYON, 2011; SALADIN D'ANGLURE, 1997 e 2007; DESCOLA, 2015). Por exemplo, Matilde Koito, filha do pã'í Vicente Fernandes Fokanh, disse-me que uma vez recebeu a visita do profeta São João Maria, no Toldo Imbu, ele travestido em uma criança. Braulino Pereira Beline, capelão da Terra Indígena Votouro, revelou-me que os santos que caminham pela terra podem assumir a forma de um animal ou de um indigente para testar a boa-fé das pessoas nos lugares por onde eles passam (ROSA, 2011; 2005; CRÉPEAU, 1997; BAPTISTA DA SILVA, 2002). 
Outra característica também presente no xamanismo kaingang é que todos os animais possuem o seu duplo. Na perspectiva de Jorge Kagnãg Garcia, a sua experiência com a sua jagrẽ onça não se reduz aos Kaingang - afinal, todos os animais possuem o seu mestre, ou "kujà dos bichinhos". Nas suas palavras:

Eu tendo a tirar conhecimento somente dos bichos, o que eles fazem no matão. Eu já vi coisas muito diferentes. Eu vi reunião dos macacos, vi reunião dos bugios, vi reunião dos pássaros, dos papagaios, caturritas. Todos eles ficam lá proseando, falando, e a gente tem que ter muita experiência para saber o que eles estão fazendo ali, tem que ter muita ideia e muita paciência pra saber o que eles estão fazendo. Eu comecei contar, o macaco, o bugio, todos eles têm o kujà deles. Àquela hora da reunião, que eles estão reunidos, proseando, alegres e falando, o kujà deles está lá dentro, alguma coisa ele está aplicando. Porque lá no mato também é perigoso, lá tem o gavião que pega eles, a onça que pega os bichinhos da terra, tatu, paca, cotia. Então, eles fazem a reunião pra eles tomarem cuidado, ali vem o conselho deles, pra se cuidar, se comportarem bem, não andarem um longe do outro. Com nós índios já era assim. Os kujà no tempo que nós vivia no mato, só nós no mato, a gente tinha que falar com ele ou com o prático dele, tem os mestres dele também, que ajudavam ele, os pej que diziam. Então, eles explicavam pra nós, o que a gente podia. Eles diziam assim: "quando você vai no mato você tem que cuidar os passarinhos, o passarinho se tem uma coisa perigosa lá na tua frente ele te avisa, ele dá um gritinho bem assim [assobio], quando ele estiver com medo você tome cuidado, tome cuidado e não ande sozinho, se tem um companheiro perto por ali, chame ele e ande junto. Você andando em dois a onça não te pula. Ela tem medo daquele que está atrás. A onça só em uma pessoa ela se bota, mas em duas...

Segundo Jorge Kagnãg Garcia, a "história do mato" ensina que todos os animais possuem três tipos de fala: a "alegre", a "triste" e a "chorosa". Esse saber relacionado ao perigo e à atenção é transmitido pelo kujà dos bichinhos aos seus animais. Ou seja, cada coletivo de espécie animal tem o seu duplo nesse caso simbolizado pelo "kujà mestre". Vamos a mais um diálogo com esse kujà. 
- Autor: "O tatu também faz reunião?"

- Jorge: "Mas claro. O tatu também tem a turma dele. Eu já vi turma de tatu, tudo um perto do outro, fuçando. Ele tem uma prosinha [imitação do som do tatu] um pro outro, eles estão proseando. Tudo quanto é bicho tem o tipo dele falar."

- Autor: "Eles são que nem nós, um fala mais, o outro menos?"

- Jorge: "Vamos comparar, é igual à pessoa: tem um que é teimoso e outro que não é teimoso, mais calmo, que procura o lado do bem, tem outros que procuram o lado do mal, é igual à pessoa. Às vezes, está aconselhando, está aconselhando eles, saem numa turma: 'aquele lá... o que eu fizer está bem feito'. Ele não se importa se está ruim ou está bom. Igual a uma pessoa. São muito mais atendidos do que nós, comendo lá na mata tudo sãozinho [sadio]. Ninguém cuida deles, mas, claro, a gente diz ninguém, mas um cuida do outro, eles têm o cuidador deles."

- Autor: "O porco do mato também tem o kujà deles?"

- Jorge: "Tem, o porco do mato, todos eles têm, o caboclo diz 'o cacique dos bichos'. A coruja, o gavião, só eu nunca ouvi falar no corvo, porque o corvo nem os kujà têm contato com eles, porque o corvo falam que ele que limpa as coisas podres, mas também diz que tem o kujà dele que manda matar pra eles terem o que comer. Tem três, quatro bicho do mato que não temos contato com eles".

Possivelmente, a fala de Jorge Kagnãg Garcia não se remete ao que entendemos enquanto corvo, mas ao urubu. O corvo trata-se do nome de um pássaro da família das gralhas (Corvideos), animal de plumagem de belas cores, mas de canto desarmônico, que se alimenta da semente do pinheiro: o pinhão. O naturalista Rodolpho Von Ihering faz menção à confusão presente na cultura popular brasileira entre o corvo e o urubu (Catartídeos, Catharista atratus brasiliensis). "As duas aves só têm em comum a uniformidade da plumagem preta; de resto, tanto no feitio, no porte, como no modo de viver, são totalmente diversas" (1968, p. 261).

Tomando ainda como referência o conhecimento de Jorge Kagnãg Garcia, apresentado aqui e no texto $O$ xamanismo kaingang, o poder e a floresta (ROSA, 2014a), é possível identificar três grupos de animais relacionados ao xamanismo, apresentados a seguir por sua ordem de importância: 
- primeiro, os animais da floresta que possuem seu kujá mestre (tatu, caititu, paca, cotia, coruja, cobra, gavião, cachorro do mato e onça);

- segundo, as aves de rapina, animal carniceiro consumidor de carne podre de animais predados por outrem, uma ação que é intencionalmente transferida pelo seu kujà mestre a outras espécies (com destaque ao urubu); e,

- terceiro, os animais domésticos, que dependem dos cuidados humanos, que habitam nas casas destes, que ficam sob a proteção dos kujà kaingang (galinha, porco, vaca e cachorro).

A partir dessa lógica kaingang, pode-se dizer que o aspecto de imperfeição dos animais do segundo grupo se deve ao fato deles abdicarem da satisfação de matar a sua presa (predação). Claude LéviStrauss (2004) chama atenção à falta de primor e ao aspecto de mediação dessa ave na mitologia ameríndia, por exemplo, ao analisar o mito Mbyá-Guarani: origem do fogo, publicado originalmente por Leon Cadogan, uma narrativa que faz referência à destruição diluviana da primeira terra e à criação de uma segunda, agora sob os cuidados de Ñanderu Papa Miri. Essa divindade tratou de roubar o fogo dos feiticeiros-urubus para repassá-lo à nova humanidade, para isso travestindo seu filho de sapo para provocar o apetite de tais abutres. Lévi-Strauss cita Cadogan: "Como punição por seu comportamento antropófago, os feiticeiros serão urubus comedores de carniça, 'que não respeitarão a coisa grande' (o cadáver) e que nunca alcançarão a vida perfeita" (2004, p. 170). Nessa narrativa, ainda, a onça apresenta-se como doadora do fogo, e o urubu, como seu dono sovina, levando o antropólogo francês a concluir que o "pensamento bororo é impregnado de mitologia tupi" (2004, p. 171).

Pode-se dizer que a diferença entre os animais da floresta do primeiro grupo e a ave de rapina carniceira do segundo grupo sugere uma relação de grau. Já a distinção entre os animais do primeiro grupo com os animais domésticos é da ordem da natureza (DESCOLA, 2002). A partir desse modelo cosmológico, a onça é o animal soberano na fauna kaingang, dado esse que se replica, segundo Reichel-Dolmatoff, em diversas sociedades da América Central e da América do Sul, constituindo o complexo xamã-jaguar (apud LANGDON, 1992, p. 41). 
No sul do Brasil, essa felina predadora se tratado animal que exige os mais apurados conhecimentos de Jorge Kagnãg Garcia:

Eu vi uma reunião das onças e vi como é que eles dão ideia um para o outro, pegar o bicho, não pegar e estragar o bicho, machucar e deixar também, todos estes conselhos eles têm, para conversar o bicho para aumentar, para não faltar para eles também, eles comem somente carne. $O$ nosso conselho também é a mesma coisa. A onça, o mestre delas, o kujà dela, é o que passa a sabedoria para as outras: "toma cuidado de muitas coisas que é perigoso, o homem também é perigoso, não pule no homem porque ele também briga". Tudo isso elas aconselham, tomar cuidado com as coisas perigosas para elas. A cobra também tem 0 kujà dela. E a onça, por que ela grita que nem uma pessoa? Mas não é a onça que grita, é o mestre dela que faz aquele movimento. Ela ronca que nem um porco, grita que nem um leitãozinho, um leitãozinho bem novinho que está recém nascendo [som], ela chora que nem uma criancinha que está nascendo, chora que nem uma criança grande, ela berra que nem um touro, ela relincha que nem um cavalo, faz tudo, mas tudo é o mestre delas que tem aquela sabedoria para ele ensinar as outras onças. As outras onças são brabas, que não são kujà, são teimosas igual a pessoa, tem gente que está falando a verdade e o outro que está abusando. Tem tudo isso também nos bichos, paca, cotia, todos eles têm o mestrezinho deles.

Na perspectiva de Jorge Kagnãg Garcia, a floresta como um todo possui essa característica, vinculada ao xamanismo kaingang - ou seja, uma espécie de mestre, o nẽn tóg (mestre da floresta). Aliás, esse modelo pertence a todos os seres da terra e do universo - flora, fauna, minerais, formação geológica, líquidos, satélites, astros luminosos e constelações. Conforme Jorge Garcia:

Por isto que o índio, nas épocas que só eles que viviam no mato, ele e deus, o deus dele era o ar, o que comanda o ar. Kanhkã tóg é pra dizer o mestre do céu, o mestre é tóg ${ }^{11}$. Rã tóg é o mestre do sol, kysã tóg é o mestre da lua, krĩg tóg é o mestre das estrelas. Aí vem para a terra: ga tóg é o mestre da terra; aí vem para a mata: nẽn tóg é o mestre do mato. Existe o mestre do mato, a gente vê movimento no mato, é ele que faz

\footnotetext{
${ }^{11}$ Lê-se "tõn".
} 
aquele movimento. Ali vem tudo de tóg. A religião dele é o mestre. Mestre, tóg. O Guarani é a mesma coisa, ele acredita no que comanda, desde a pedra, a pedra também tem tóg, um perau [barranco], um perauzão grande, dá um movimento naquele perau, ele diz poró tóg, é o mestre que está fazendo aquele movimento. A água, você tem que ter muita prática para entender o que a água está proseando também, tem hora que ela proseia. Você pode notar tem hora que ela diferencia aquele som dela, que ela tem um sonzinho, que ela está escorrendo, ela muda, tem uma hora que ela muda o som, tem que saber o quê que é, se é para chuva, se é para tempo bom, ela explica. Tem que ter a sabedoria daquela hora.

No pensamento de Jorge Kagnãg Garcia, todos os seres têm tóg, palavra traduzida por ele por "comando", sendo que, em se tratando dos humanos e dos animais do primeiro (predadores, rapina) e segundo grupos (carniceiros), esse princípio universal encontra o seu equivalente na agência do kujà mestre de cada espécie. Aliás, essa regra se replica no caso dos jagrẽ. Ou seja, assim como entre os Kaingang, através da relação dos kujà com seus jagrẽ, os kujà animais da floresta também possuem os seus respectivos jagrẽ. Mas, a seguinte diferença se apresenta nesse relacionamento: enquanto os kujà kaingang têm uma diversidade de jagrẽ - que assumem tanto a forma não humana como humana, ou seja, espírito animal da floresta, espírito vegetal da floresta, espírito da água e santos do panteão do catolicismo popular-, os kujà dos bichinhos possuem exclusivamente espíritos animais de mesma espécie. Ou seja, o kujà tatu tem como jagrẽ o espírito mestre tatu, e assim por diante. Eis um novo diálogo:

- Autor: "Os bichinhos têm kujà, o kujà dos bichinhos tem guia, tem espírito auxiliar?"

- Jorge: "É claro. O mesmo próprio Topé, o nosso deus, é deus pra eles, como eu falei antes, cada toldo de índio, que na época era toldo, tinha um kujà, que é feito de deus, não é qualquer um que chega nessa altura, que deus não dá pra tudo uma experiência boa, calma, linda pra criar o povo, criar a comunidade, tem que ser uma pessoa de experiência muito firme, legal, não errar, não judiar das pessoas. Então, os passarinhos são a mesma coisa, tem o guia deles já feito do mesmo jeito do índio. Nós considerando, nós somos igual aos passarinhos no mato, a nossa 
sabedoria. Na escola não tivemos tempo de aprender, esse negócio de escola é novo, os mais antigos se foram [faleceram] já. Hoje que os nossos filhos estão aprendendo na escola. O mundo vai mudando, vai mudando, pode ser que uma hora dê certo. Não tem como nós dizer eu vou me criar só lá no mato, não tem mais, não adianta. Eu fui criado só no mato".

A partir dessa lógica de Jorge Kagnãg Garcia, todos os seres são regidos por um princípio comum. Pode-se concluir que a relação de similaridade entre kujà kaingang/jagrẽ e kujá dos bichinhos/jagrẽ animal de mesma espécie comunica uma dimensão monista do universo, ou seja, uma doutrina segundo a qual o conjunto dos seres pode ser reduzido a uma unidade, aspecto que caracteriza a milenar religião dos povos autóctones (LEGROS, 2007; CRÉPEAU, 2012). Segundo Dominique Legros:

O postulado comum as religiões monistas é que o universo no qual nós vivemos é um Todo único e imanente. Ele compreende a terra, os astros que habitam o céu e todos os fenômenos que ocorrem nesse vasto espaço (2007, p. 136).

No próximo tópico, apresentarei uma breve retrospectiva acerca da minha parceria com Jorge Kagnãg Garcia nas duas últimas décadas, destacando as transformações de identidade vivenciadas por esse homem.

\section{A parceria do etnólogo com o kujà Jorge Kagnãg Garcia}

Ao iniciar esse tópico, relembrando ainda as falas de Jorge Kagnãg Garcia transcritas acima, eu me indago de onde vem tamanha sabedoria. Aliás, em todas as vezes em que me deparo com esse velho homem, surpreendo-me com a sua capacidade de transformação frente ao outro e ao novo. Ou seja, cabe dizer agora que, em nossa parceria de praticamente duas décadas, aminha percepção de estar na frente de um kujà dessa grandeza não aconteceu em nosso primeiro encontro.

Quando, em maio de 1999, eu cheguei ao Capão Alto para a realização da perícia antropológica Kaingang de Nonoai (ROSA, 2000), 
Jorge Kagnãg Garcia, então com oitenta anos, apresentou-se como "conselheiro" e originário da Terra Indígena Nonoai. Ele não se nominou kujà nem para mim, nem para os demais Kaingang. Em um dia de trabalho de agosto de 1999, na divisa do encontro da barra do Nünüaj goj (lajeado Nonoai) com o lajeado do Crespo, Jorge falou sobre a caça nesse capão à beira da água.

Quando eu tinha dezesseis anos, hoje tô com oitenta, a gente vinha caçar por aqui, pescar, posávamos, mas aqui tinha bicho a reviria. $O$ quê que a gente procurava tinha. Tinha paca, tinha tatu, o veado que, o índio, ele nunca gostou de caçar o veado. Ele gostava assim dum quati, a paca, o tatu e eles gostavam de matar muita anta, na época existia. Que aqui era umas partes campos, outras partes devassadas, essas barbas de bode, mas não era grande coisa assim também. As coxilha lá em cima, lá têm os capão de capoeira, capão de faxinais que dizem, mas na baixada assim era pinhal, era matão, era sertão feio, taquaral, que existia nessas beira de sanga. Aqui existia até porco do mato que dizem. Hoje, se fala, não existe mais nada, vai terminando. E, o quê que a gente pode fazer? É das épocas que foi invadido as terras, nós se arrecuamo lá pra banda do mato, porque o índio é do mato. Hoje tamo revortando pra consegui a terra de volta, que já tava invadido mesmo, invadido completamente. Desde a época, que faz vinte e um ano, que era a época dos invasores, esta terra foi invadida. Então, ali nós começamo a se perde. Hoje não se conhece mais, não se acha mais um marco, que arrancaram tudo, claro, as divisas das áreas, nossa querida terra brasileira, que é um pedacinho pequenininho do Brasil, mas a gente, é só essa que nós temo. $\mathrm{E}$ os caras tão matando nós espremido (ROSA, 2000, p. 170).

O motivo desse texto era periciar a área reivindicada pelos Kaingang de Nonoai, conforme a demarcação realizada pela Diretoria de Terras e Colonização do Estado do Rio Grande do Sul, em 1911, ocupada naquele momento pela Companhia Agro-Pastoril [sic] Alto Uruguai. O depoimento mostra Jorge Kagnãg Garcia indignado com a situação de opressão por parte do Estado e da empresa. Trata-se de um discurso político reivindicatório, articulado na oratória de uma liderança política (GALLOIS, 1993). A relação com os animais aparece enquanto uma antiga atividade de caça no espaço usurpado, não havendo 
referências à dimensão espiritual. Todavia, impressionado com seus conhecimentos gerais sobre as divisas, sua memória e sua dedicação à perícia, manifestei meu "profundo respeito e admiração por este velho mestre dos Kaingang de Nonoai" no documento final entregue à Funai (ROSA, 2000, p. 19).

Movido por esse sentimento, em novembro de 2000, indiquei Jorge Kagnãg Garcia à equipe da Cooperativa de Vídeo, essa contratada pela Secretaria Estadual da Educação/Governo do Rio Grande do Sul12 para a realização do Kanhgág Ag Kãme (Histórias Kaingang). A partir do roteiro desse documentário, a professora Martina Kagmũ Lopes Nascimento incentiva os seus alunos a saírem da escola indígena para conversar com os velhos sobre o saber kaingang em suas casas. Assim, os anciões Argemiro Pereira, Julio Silva, João dos Santos, Maria Constante Garcia e Jorge Kagnãg Garcia falaram sobre animais e rituais de caça, rezaram, produziram artesanato, enfim, abordaram aspectos da cultura kaingang ligados à floresta.

Como de praxe, Jorge Kagnãg Garcia se destacou durante as gravações do DVD. Ele apareceu desde as primeiras imagens até os créditos finais do Kanhgág Ag Kãme. Particularmente, ele falou sobre comidas típicas, coleta de sementes, pesca artesanal, caçadas, cozimento de grandes animais em fogos subterrâneos; além disso, apresentou uma narrativa mitológica sobre a construção da casa pelo veado e pelo tigre, além da inteligência do macaco. Durante a preparação dovẽnh-kagta (remédio do mato), colhido no Mĩg goj (lajeado do Tigre), ele registrou o seguinte:

Meio sofrendo, mas nós não morremos, porque os nossos remédios estão aqui, o remédio que nos cura. Hoje os brancos falam em sarampo. Às vezes, as doenças infiltram-se entre os Kaingang, mas eles se curam sozinhos. Também tem os kujà para curar os seus parentes, seus filhos, seus cunhados. Portanto, era boa a vivência dos Kaingang, os brancos que mudaram. Hoje queremos ser iguais aos brancos, mas não poderia ser assim, não devíamos deixar. Nós deveríamos seguir o nosso sistema, pois existem ainda os nossos velhos, os velhos kaingang. São bastante ainda os Kaingang antigos. Os kujà eram assim, depois

\footnotetext{
${ }^{12}$ Projeto realizado pelo Núcleo de Educação Indígena, Coordenado pelo Prof. Rodrigo Alegretti Venzon.
} 
de queimarem as ervas do mato, depois que todos participam, eles ficam muito felizes, cantam para seus filhos. O fogo fica assim aceso, e a erva ainda não acabou de queimar, então ele canta para seus filhos, e seus filhos dizem a ele: "cante alguma coisa pra nós, pra nos alegrar", então ele diz: "tá bom, então fiquem quietos pra eu cantar pra vocês" (documentário Kanhgág Ag Kãme).

Então, como em sua fala "os kujà eram assim, depois de queimarem as ervas do mato [eles] cantam para seus filhos", na cena seguinte, Jorge Kagnãg Garcia cantou e dançou. No documentário, coube a João Maria Fortes a realização da legenda em Kaingang de seu canto:

Reregrá, vá fi mỹ kej há nỹ ké, reregrá vá fim ỹ kej há nỹ ké, kej há nỹ ké, kej há nỹ ké.

Reregrá vá fimỹ kej há nỹ ké, kej há nỹ ké, kej há nỹ ké.

Tỹ kygryg, krygryg, kygryg gé [batendo os pés no chão], tỹ kygryg, kygryg, kygryg gé.

Kuri nĩ vá, há...

Então, vai ser bom para os nossos filhos, depois de beber os remédios dos meus parentes.

Reregrá, vá fi mỹ kej há nỹ ké,

kej há nỹ ké, reregrá vá fim ỹ kej há nỹ ké, kej há nỹ ké, Tỹ kygryg, krygryg, kygryg gé [batendo os pés no chão], tỹ kygryg, krygryg, kygryg gé.

Relendo esses dados de forma retrospectiva, tenho a impressão de que Jorge Kagnãg Garcia, ao evocar os kujà durante a preparação do vẽnh-kagta - "Os kujà eram assim..." - e, logo a seguir, ao cantar "Reregrá, vá fi mỹ kej há nỹ ké" - recobra a memória dessa chefia desprendida. Enfim, a voz e a atuação desse homem frente a câmeras de vídeo e fotografias, microfones, refletores, rebatedores e cabos arrebataram a equipe de produção. Desse modo, a diretora Karine Emerich manteve duas vezes essa imagem na versão final do 
documentário, uma no bloco Remédios do Mato e, depois, nos créditos finais.

Então, impressionado com o talento musical de Jorge Kagnãg Garcia registrado no DVD, o momento seguinte de nossa aproximação foi a realização do CD Kanhgãg Jykre (Pensamento Kaingang). Esse trabalho conectou dois registros sonoros: primeiro, as gravações das rezas do Kiki, realizadas pelos Kaingang do Xapecozinho e Palmas (Paraná), na década de 1990, a partir do projeto Ritual do Kiki: Imagens Antropológicas, uma realização da Universidade Federal do Rio Grande do Sul, Universidade Federal de Santa Catarina (UFSC) e Université de Montréal (UdM)13; segundo, o registro das rezas, cantos e diálogos dos Kaingang gravados nas terras indígenas Nonoai, Votouro e Xapecozinho, a partir de setembro de 2000, agora vinculados ao projeto Série CD Vertentes, uma realização do Museu Antropológico do Rio Grande do Sul (MARS/Governo do Estado do RS) ${ }^{14}$, Núcleo de Antropologia das Sociedades Indígenas e Tradicionais (NIT/UFRGS), Programa de PósGraduação em Antropologia Social (PPGAS-UFRGS) e Selo Quartavia. ${ }^{15}$

$\mathrm{Na}$ versão final desse $\mathrm{CD}$ - em parceria com os rezadores/kujà/músicos Chapecozinho, Chiquinho da Silva, João dos Santos, José Arcanjo, José Gabriel, Luisa Jagnĩgri Pedroso, Pica Pau, Simplicio, o pã'í Vicente Fernandes Fokanh e o professor bilíngue Dorvalino Refej Cardoso -, nosso ancião Jorge Kagnãg Garcia gravou três faixas. Vejamos:

Faixa $\mathrm{n}^{\circ} 3(1 \mathrm{~m} 18 \mathrm{~s})$, intitulada Vênhkanẽn Nonohánh:

Gufã Ta Vẽnhpãkár Ja, Ti Krẽ Ag Mỹ.

Sor Gufã Jiji.

Sor vỹ jã, sor vỹ jã, sor vỹ jã

ti jamré kaja finh ke tĩn kỹ.

\footnotetext{
${ }_{13}$ Projeto coordenado pela Prof ${ }^{a}$. Cornelia Eckert (PPGAS-UFRGS) e Prof ${ }^{a}$. Esther Jean Langdon (PPGAS-UFSC), consultor Prof. Robert R. Crépeau (UdM). As rezas do Kiki foram gravadas pela Prof ${ }^{a}$. Eliana Diehl, Prof. José Otávio Catafesto de Souza, Ledson Kurtz de Almeida, Maria Conceição de Oliveira, Moacir Haverroth, Ricardo Cid Fernandes, Prof. Robert R. Crépeau, Rogério Reus Gonçalves da Rosa e Carolina Rodrigues Paz.

${ }^{14}$ Pelo MARS, participaram Walmir da Silva Pereira, José do Nascimento Junior e Maria Luiza Santos Soares.

${ }^{15}$ No Série CD Vertentes, as faixas foram registradas pelo Prof. Dorvalino Refej Cardoso, Fabio da Veiga Torres, Jorge Herrmann e Rogério Reus Gonçalves da Rosa.
} 
Jãtãnh mág, jãtãnh mág, jãtãnh mág

kãmi ti kre tãm kãmũ ki jẽ

Sor vỹ jã, sor vỹ já, sor vỹ já, sor vỹ jã

kri nĩ kỹ.

Ti róg'ro pu tỹ vẽjó gỹ kỹ nin kỹ.

Ti kãtĩ mỹr,

ti kato ti kã tỹ róg ke kỹ.

Ka vẽnhig kỹ fi kar tĩn kỹ.

En no ta katánh mág kỹ ta,

tánh, tánh, tánh, tánh, hẽnh tó!! hẽnh tó!!

Vẽnh jamré. 16

Faixa $n^{\circ} 7$ (4m04s), essa se divide em três cantos de festas:

\section{Kikikonh To Tỹnh}

“Jamré inh mỹ ũg sĩ fãn isỹ ã mỹ tỹ jé.

He jẽ jẽ jẽ jẽ jẽ

tỹ kron kron gé, tỹ kron kron gé.

Cunhado, me dá um pouco de bebida, que eu vou cantar!17

Hinh Ta Ti Jamré Mỹ Tánh

"Tỹnh ra jamré! kron nĩ hãra

Péhe mẽ mẽ mẽ

péhe mẽ mẽ mẽ

péhe mẽ mẽ mẽ

péhe,

- ra, jamré?!18

Jag Rég' Re Ag, Ag Prũ Fi Mré Vẽnhgrég

"Kỹ ti rég're ta ti mỹ!

\footnotetext{
16 “Canto que o velho Nonohánh cantava, alertando para os perigos da noite, aqui personificados na figura de Sor prea, um índio muito valente e antigo, que sempre podia estar à espreita. No canto, diz-se que se Sor prea se aproximar, será atravessado pelo facão e que depois disso, o facão será cravado no tronco de uma árvore, onde as moscas lamberão o sangue de Sor prea. No "hehn tó! henh tó!!", Nonohanh fazia o alerta final, lembrando que a qualquer momento talvez fosse preciso despertar para defender a vida". Gravação no Capão Alto, fevereiro 2001 (tradução presente no encarte do CD Kanhgág Jykre).

17 "Canto realizado durante o ritual do Kikikonh. Todos dançavam na marcação do ritmo, cantavam ou tocavam instrumentos, como o taquaruçu, que era percutido no chão, e a flauta. $\mathrm{O}$ cantor pede que aumentem os sons dos instrumentos porque ele vai aumentar o som da sua voz" (idem).

18 “O índio Fã Fãn / Tatu canta e toca para seu cunhado. No final, ele lembra o cunhado que, afinal, também sabe cantar" (idem).
} 
Rég're ã jamré

fi mré vẽnhgrég ke mũ,

kỹ fi ta ti mỹ

mũnỹ vẽnhgrég jé, jamré ke mũ.

Rég're vá fi mũ ke hag ra ké

Rég're vá fi mũ ke hag ra ké

Rég're vá fi mũ ke hag ra ké

Fi kur rá ẽg ve kỹ fi mỹ ke

Hag ra ké, ke hag ra ké,

ke hag ra ké. 19

A faixa $\mathrm{n}^{\circ} 38$ ( $\left.2 \mathrm{~m} 18 \mathrm{~s}\right)$ é admirável, pois se trata de um canto de saudação entre jãmré (cunhados), gravada em parceria por Jorge Kagnãg Garcia e Vicente Fernandes Fokanh. É bom lembrar que, nos anos 1990, o Kiki era organizado no Xapecozinho pelo pã'í Vicente Fernandes Fokanh. Jorge pertence à metade kamẽ; Vicente, à metade kanhru. Conforme encarte do CD Kanhgág Jykre, Jorge sai à procura do cunhado Vicente, indo em direção à nascente do sol, subindo e descendo o morro, atravessando a coxilha. Os dois se encontram finalmente e, a partir disso, fazem o canto de cumprimento 20.

A minha admiração e respeito por esse velho e sua família não para de crescer. Eu novamente vou ao encontro deles durante o trabalho de campo que realizei entre os Kaingang do Votouro, em 2003, agora para fins de minha tese de doutoramento no PPGAS/UFRGS. A partir do meu projeto, o objetivo era analisar como se estruturava o sistema cosmológico xamânico kaingang no Votouro. Dessa terra indígena, decido atravessar o rio Passo Fundo para conversar com meu ancião amigo Jorge Kagnãg Garcia sobre esse tema. No decorrer de minhas idas, descubro que ele nascera no Votouro e, muito jovem, partira para Nonoai, onde conheceu e se casou com Maria Constante Garcia.

Sobre minha pesquisa a respeito do xamanismo kaingang, na fria noite de 11 de março de 2003, na penumbra de uma lamparina de querosene acesa no pequeno ing-xim (paiol) repleto de espigas de milho para os animais, construído ao lado da sua casa no Capão Alto,

19 “O irmão convida o irmão para dançar com sua mulher. Enquanto eles dançam, canta para ela dançar animadamente, pois o seu vestido é muito bonito" (idem).

${ }^{20}$ Esse registro extraordinário foi gravado na casa de Jorge Herrmann, no bairro IAPI, em Porto Alegre, em abril de 2002 (idem). 
Jorge Kagnãg Garcia me falou pela primeira vez acerca do sistema kujà e do sistema caboclo, apresentados em tópico acima como partes do complexo xamânico kaingang (ROSA, 2005).

- Autor: "A Festa do Divino Espírito Santo não era do sistema kujà?"

- Jorge: "Não, era caboclo!"

- Autor: "O que é sistema kujà?"

- Jorge: "Sistema kujà? O kujà é só a tradição dele, do índio. Essas partes já da religião que hoje diz religião católica, eu penso assim que ele já começou a abraçar junto com o branco. Fazer um terço assim no português. Sessenta, setenta anos começaram a fazer esses intrusos de religião, com a religião indígena. Puro índio já existe muito pouco, a maior parte já foi mestiçado."

- Autor: "O que veio depois do sistema kujà?"

- Jorge: "Pois é, o que veio é o sistema caboclo, hoje desde um baile, festa isso aí é do sistema caboclo" (ROSA, 2005, p. 183).

A conversa com Jorge Kagnãg Garcia avançou à noite. A ideia de sistema kujá e sistema caboclo agora se conectou ao que esse homem disse durante a preparação do vẽnh-kagta, apresentado no documentário Kanhgág Ag Kãme: "Hoje queremos ser iguais aos brancos [...]. Nós deveríamos seguir o nosso sistema, pois existem ainda os nossos velhos, os velhos kaingang". Eu saí do iñg-xim de Jorge pensando em reencontrar Madalena de Paula, Darci Brandino, Braulino Pereira Beline e Joane Xavier Rigon no Votouro para saber mais sobre altarzinhos e igrejinhas de tabuinhas, porque descobri suas vinculações ao sistema caboclo. Entre outros, esses anciões, portadores de trajetórias únicas, trouxeram uma contribuição notável à minha tese, mas foi seu Jorge que - assentado em sua larga experiência com os espíritos e com os bichinhos da floresta, revelando as noções sistema kujá e sistema caboclo21 - possibilitou-me a construção etnológica do complexo xamânico kaingang.

Durante as demais entrevistas gravadas para fins de meu doutorado, entre 2003 e 2004, Jorge Kagnãg Garcia passou a se assumir

\footnotetext{
${ }^{21}$ Além das noções em destaque sistema kujà e sistema caboclo na tese " "Os Kujà são Diferentes'..." (ROSA, 2005), Jorge Kagnãg Garcia trouxe durante o trabalho de campo as categorias "sistema antigo", "sistema escola", "sistema indígena", "sistema índio", "sistema do índio", "sistema branco" e "sistema do branco".
} 
como "ex-kujà", mas no sentido inverso ao uso do prefixo "ex" em português: ele toma para si cada vez mais a categoria kujà. No meu entendimento, após seu processo de formação junto ao kujà Pedro Constante e os primeiros anos de trabalho nessa chefia, seu Jorge ingressou em um período de entorpecimento xamânico, resguardandose para o cuidado dos mais próximos. Em suas palavras:

Como eu não estou me gabando, eu sei muito remédio, só que eu não quis pegar aquele caminho de kujà. No meu entender, no meu sonho que alcancei, era pra mim dar remédio dez anos sem cobrar um pila [dinheiro]. Também achei demais, é muita dificuldade, às vezes, eu morava aqui no lajeado Grande, tinha uma pessoa mal lá no Pinhalzinho, eles sabiam que eu dava remédio bem, uma época que eu trabalhei com isso eu dava remédio, entendia muitas coisas, eu estava bem adiantado, eles vinham me pegar fora de hora. Às vezes, chuva, bem frio, a pé, saia do lajeado Grande, dava uns vinte quilômetros, estradinha misturada com mato, era muito ruim, chegou uma época que eu enjoei, não ganhava nada, não podia cobrar mesmo, se eu cobrasse daí não valia os trabalhos. Depois de dez anos sim, eu podia cobrar; eu achei demais, eu abandonei. Hoje eu faço remédio assim pros filhos, para quem me pede, faço benzimento, não para todo mundo, parente; então, eu tenho muita lida do mesmo kujà.

Então, durante esse período de hibernação, nas poucas vezes que Jorge Kagnãg Garcia esteve doente - ele disse com orgulho que é um homem sadio: "nunca deitei em uma cama de hospital porque nunca desgarrei da raiz" - o próprio kujà se dirigia ao curandor caboclo de sua confiança, que morava em Nonoai, o João Lopes.

Um dia fui lá pedir um remédio pra mim; só ele [João Lopes] me disse: "oh, seu Jorge, vou te fazer um litro de remédio" - na época eu tomava muita pinga, gostava de tomar - "vou te fazer remédio, você tome esse litro de remédio, se você quer sarar, você não tome mais pinga, se você continuar tomando pinga, você não vai durar muito. Me desculpe, mas eu vou te dizer. Tome bem direitinho como eu vou te explicar, vou te dar um passe aqui, mas se o senhor voltar a tomar de novo a pinga pode contar com o que eu estou Ihe dizendo. 
Esse dado mostra o respeito dos Kaingang, mesmo dos mais renomados kujà, pelo trabalho xamânico realizado pelos curandores caboclos (ROSA, 2005). Depois de defender a tese inúmeras vezes (nos anos 2008, 2012, 2013, 2014, 2015, 2016 e 2017), eu visitei Jorge Kagnãg Garcia e sua família em sua casa no Capão Alto. Em todas essas oportunidades, ele me cedeu entrevistas não mais como um ex-kujà, mas como um grande kujà. Em 2012, ele me comunicou pela primeira vez que passou seu dom ao filho Pedro Pó Mág Garcia. Esse dado ficou registrado na versão final do Kanhgág Kanhróz2 (Sabedoria Kaingang), de 2015.

Pode-se dizer que, nos últimos anos, o trabalho e o prestígio de Jorge Kagnãg Garcia saíram do "matão" da Terra Indígena Nonoai em direção às grandes cidades brasileiras e às universidades. Para citar alguns exemplos disso, pelo Instituto Indígena para Propriedade Intelectual (INBRAPI), Jorge viaja de avião a Recife, Brasília, Rio de Janeiro e Florianópolis, no sentido de promover, divulgar, revitalizar e valorizar a cultura kaingang (KAINGANG, 2013). Da mesma forma, pela Política Nacional de Gestão Territorial e Ambiental de Terras Indígenas (PNGATI/Funai), esse kujà chega a São Paulo para participar do Curso Básico de Formação em Política Nacional de Gestão Territorial e Ambiental de Terras Indígenas, em 2014. Pela Prefeitura Municipal de Porto Alegre, ele se torna o líder espiritual do Encontro dos Kujà, evento realizado na aldeia Ỹmã Topẽ Pẽn (Morro do Osso), desde 2006. Pela Faculdade de Educação (FAE/UFRGS), Jorge assume o trabalho de mestre indígena do Programa de Formação Continuada de Professores Kaingang Saberes Indígenas na Escola e se torna bolsista pesquisador da Secretaria de Educação Continuada, Alfabetização e Diversidade do Ministério da Educação23 (SECADI/MEC). Enfim, Jorge Kagnãg Garcia tornou-se uma referência acerca dos saberes relacionados aos Kaingang

\footnotetext{
${ }^{22} \mathrm{O}$ documentário Kanhgág Kanhró é uma produção da PH7 e Flow Films, dirigida por Karine Emerich e Rogério Reus Gonçalves da Rosa, fotografia e montagem Hopi Chapman, tendo apoio da TVE-RS, IECINE e Pró-Cultura RS/Governo do Estado do RS. A sinopse fala sobre as interações, a amizade e os conflitos de dois velhos kaingang no sul do Brasil. É um percurso com os nonagenários Kasu e seu Jorge em Porto Alegre (aldeias Lomba do Pinheiro e Morro do Osso), São Leopoldo (Por Fi Gá) e Nonoai (Terra Indígena Nonoai). Aborda-se a memória, os rituais e a luta política desse povo ligado à floresta na segunda década do século XXI.

${ }^{23}$ Informações cedidas pela Prof ${ }^{a}$. Maria Aparecida Bergamaschi (comunicação pessoal).
} 
e à etnologia ameríndia em livros, relatórios, dissertações, teses e publicações de várias universidades brasileiras e do exterior.

Enfim, se décadas atrás o trabalho de cura e a realização do ritual do Kiki pelos kujà foram proibidos pelo Serviço de Proteção ao Índio (SPI) e, depois, pela Funai, através do estabelecimento de políticas públicas anti-indígenas, incluindo a instalação de postos indígenas, serrarias, enfermarias, escolas e igrejas, agora o trabalho de Jorge Kagnãg Garcia conquistou uma visibilidade inimaginável.

Imagem 1: Jorge Kagnãg Garcia.



Fonte: Fotografia de Rogério Reus Gonçalves da Rosa (2008). 
No último tópico, falarei de forma breve sobre a transmissão do legado de Jorge Kagnãg Garcia e a responsabilização que caberá às gerações mais novas kaingang pela conservação desse saber.

\section{O legado de Jorge Kagnãg Garcia e a continuidade desse saber no futuro}

Sabemos agora que Jorge Kagnãg Garcia tem noventa e sete anos, trata-se de um homem com boa saúde e disposição; afinal, ele segue uma rotina de trabalho vinculado à floresta e a vários projetos institucionais. O desafio posto é pensar a responsabilização e a continuidade do legado disponibilizado por esse kujà às próximas gerações. Sobre isso, enumero quatro aspectos:

Em primeiro lugar, Jorge Kagnãg Garcia e as inúmeras pessoas que o buscam já materializaram em artigos, livros, relatórios, dissertações de mestrado, teses de doutorado, CDs, DVDs, blogs, etc.na língua kaingang, em português e francês -, os conhecimentos ligados ao xamanismo kaingang e à floresta. A partir disso, caciques, agentes públicos, jornalistas, cientistas, estudantes e o público em geral podem acessar essas informações e refletir sobre o futuro dos povos autóctones, além do nosso devir enquanto parte do Ocidente. Em outras palavras, o pensamento desse homem está em comparação com os saberes de diversos xamãs e povos originários do mundo e, portanto, em plena ação de interculturalidade (BENITES, 2015).

Em segundo lugar, as relações de dominação entre Estado e Kaingang e entre os próprios Kaingang no interior de suas terras não se transformarão se não ocorrer um comprometimento de todos com o plantio e com a preservação das florestas existentes, considerando essas enquanto matas, rios, nascentes, águas, animais, peixes, minerais, espíritos e visões de mundo. $\mathrm{O}$ avanço do cultivo da forrageira soja (Glycine max) sobre as florestas nativas nas terras indígenas kaingang é um duro revés aos projetos exaustivamente levados à frente por kujà, pã'í e professores bilíngues, além de pesquisadores e indigenistas. 
Em terceiro lugar, a partir da experiência do kujà Jorge Kagnãg Garcia, seguindo-se o modelo das igrejas pentecostais kaingang, devese pensar na instalação de espaços de formação específicos nas terras indígenas, preferivelmente no interior das florestas, para os kujà realizarem oficinas de estudo e rituais, eventos em que eles poderão transmitir os seus conhecimentos sobre cantos, rezas, bichinhos e espíritos aos jovens kaingang e aos demais interessados. No Xapecozinho, por exemplo, o rezador João Maria e o professor bilíngüe Pedro Kresó, da Escola Indígena de Educação Básica Cacique Vanhkre, estão estruturando um projeto de formação de novos rezadores do Kiki. A concepção é construir uma pequena casa de folhas na floresta, edificada com materiais da própria mata, onde serão ensinados as rezas e os cantos do Kiki aos mais novos. Será um trabalho restrito a alguns. Depois disso, a ideia inicial é que essa experiência seja trazida para um livro, em que constará a escrita e o contexto de práticas das rezas (PINHEIRO, 2013).

Em quarto lugar, as gerações mais novas kaingang precisam se apropriar e se responsabilizar pela continuidade dos saberes de Jorge Kagnãg Garcia, entre outros anciões, sobre a floresta, os remédios vegetais, os bichinhos e os seus espíritos. Nesse objetivo, é imprescindível a participação de pesquisadores e, em particular, dos professores bilíngues, considerando-se, ainda, a necessidade do domínio da língua kaingang, dos processos próprios de ensino e aprendizagem, da tradução e do repasse desses conhecimentos para a vida desses jovens agora e em um futuro próximo.

Por fim, na minha vida, eu tive o privilégio de conhecer dois anciões kaingang que marcaram de forma decisiva o pensamento etnológico nas últimas décadas: o pã'í Vicente Fernandes Fokanh e o kujà Jorge Kagnãg Garcia. Particularmente, em relação ao segundo, a quem eu reverencio nesse texto, digo o seguinte: seu Jorge tornou-se/é uma pessoa imprescindível à minha vida. Em nosso relacionamento, o maior desafio para mim foi traduzir, a partir da etnologia ameríndia e da mitologia, a sabedoria do meu professor e "avô" kaingang.

\section{Referências bibliográficas}


BAPTISTA DA SILVA, Sérgio. Dualismo e Cosmologia Kaingang: o xamã e o domínio da floresta. Horizontes Antropológicos, Porto Alegre, v. 8, n. 18, p. 189-209, 2002.

BENITES, Sandra. Nhe'ë, reko porã rã: nhemboea oexakarë. Fundamentos da pessoa guarani, nosso bem-estar futuro (educação tradicional): o olhar distorcido da escola. Florianópolis: Licenciatura Intercultural Indígena do Sul da Mata Atlântica/UFSC, 2015.

CHAUMEIL, Jean-Pierre. Voir Savoir Pouvoir: Le Chamanisme chez les Yagua de l'Amazonie péruvienne. Genéve: Georg Editeur, 2000.

CRÉPEAU, Robert R. Entre Diversité et Unité: le chamanisme. Recherches Amérindiennes au Québec, v. 18, n. 2-3, 1988a.

Le Chamane Achuar: thérapeutique et socio-politique. Recherches Amérindiennes au Québec, v. 18, n. 2-3, 1988 b.

Le chamane croit-il vraiment à ses manipulations et à leurs fondements intellectuels.Recherches Amérindiennes au Québec, v. 28, n. 3-4, 1997.

Les Substances du Chamanisme: perspectives sud-amérindiennes. Anthropologie et Societés, v. 31, n. 3, 2007.

Les défis du pluralisme religieux pour la pratique du chamanisme chez les Kaingang du Brésil méridionel. In: BOUSQUET, Marie-Pierre; CRÉPEAU, Robert R (Org.). Dynamiques religieuses des autochtones des Amériques. Paris: Karthala, collection Hommes et sociétés, 2012. p. 303-331.

Les animaux obéissent aussi à la religion: paradoxes du chamanisme kaingang (Brésil) en contexte pluraliste. In: LAUGRAND, Frédéric; CROS, Michèle; BONDAZ, Julien (Org.). Liaisons animales:Questions d'affects. Québec, 2015. p. 229-249.

CRÉPEAU, Robert R., ROSA, Rogério Reus Gonçalves da. Actualité et transformations de la Fête des morts chez les Kaingang du Brésil méridional.In: POIRIER, Sylvie; BOUSQUET, Marie-Pierre. In: Formes et contenus des pratiques liées à la mort chez les autochtones. Montréal (Canada): Frontières, no prelo.

DESCOLA, Philippe. Genealogia de objetos e antropologia da objetivação.Horizontes Antropológicos, Porto Alegre, v. 8, n. 18, p. 93-112, 2002.

2015.

Além de natureza e Cultura. Tessituras, Pelotas, v. 3, n. 1, p. 7-33, jan./jun.

FREITAS, Ana Elisa de Castro. Ocupação do Espaço Avaliação Ambiental das Terras do Capão Alto Terra Indígena Nonohay, RS. In: ROSA, Rogério Reus Gonçalves da. Kaingang de Nonoai: A Chegada dos Brancos, a Transformação do Espaço e a Luta pelo Capão Alto (Perícia Antropológica). Porto Alegre: NIT-UFRGS, 2000, 44pp.

FREITAS, Ana Elisa de Castro, ROKÀG, Francisco dos Santos. O kujà e o sistema de medicina tradicional kaingang - "por uma política do respeito": Relatório do II Encontro dos Kujà, Terra Indígena Kaingang Morro do Osso, Porto Alegre, Rio Grande do Sul, Brasil. In: ROSA, Rogério Reus Gonçalves da. Cadernos do LEPAARQ, V. IV, $n^{\circ}$ 7/8. Pelotas, RS: Editora da UFPEL. Ago/Dez 2007, p. 201-239. 
Rosa - O kujà Jorge Kagnãg Garcia: o xamanismo, a sua vida e o estado de espírito kaingang...

GALLOIS, Dominique Tilkin. Mairi Revisitada: a reintegração da Fortaleza de Macapá na tradição oral dos Waiãpi. São Paulo: NHII/USP/FAPESP, 1993.

HAMAYON, Roberte N. El chamanismo siberiano. In: Chamanismos de ayer y hoy. México: Universidad Nacional Autónoma de México, 2011.

JACODSEN, Joziléia Daniza Jagso Inácio. A Importância do Grafismo Para A Preservação e Valorização da Cultura Kaingáng.In: KAINGÁNG, Suzana Fakój (Org.) Ẽg Rá:Nossas Marcas. São Paulo: DM Projetos Especiais,2013. p. 13-44.

KAINGÁNG, Suzana Fakój. Ẽg Rá: Nossas Marcas. São Paulo: DM Projetos Especiais, 2013.

LANGDON, Jean Matteson. Xamanismo no Brasil. Florianópolis: Editora da UFSC, 1996.

LANGDON, Jean Matteson; BAER, Gerhard (Org.). Portals of Power: Shamanism in South America. Albuquerque: Univerdity of New Mexico Press, 1992.

LEGROS, Dominique. Traduire la religiosité amérindienne. Théologiques, Montréal, v. 15, n. 2, p. 133-161, 2007.

LÉVI-STRAUSS, Claude. O Cru E O Cozido. São Paulo: Cosac\&Naify, 2004.

MARÉCHAL, Clementine. Eu luto desde que me conheço como gente: Territorialidades e cosmopolítica Kanhgág:enfrentando o poder colonial no sul do Brasil. 2015. Dissertação (Mestrado em Antropologia Social) - Porto Alegre, Universidade Federal do Rio Grande do Sul, [2015].

NASCIMENTO, Márcia Gojtẽn. Ẽg Vĩ Kãmén Sĩnvĩ Han:As Artes da Palavra no Kaingang. In: BERGAMASCHI, Maria Aparecida; VENZON, Rodrigo (Org.). Pensando a Educação Kaingang. Pelotas: Editora Universidade/UFPel, 2010. p. 73100.

PERRIN, Michel. Théories et Pratiques Médicales des Indiens Goajiro. Actes du XLIIe Congrès International des Américanistes, Paris, v. 6, p. 387-405,1978.

Formes de la Communication Chamanique : exemple Guajiro. In: Congrès International Américanistes, E.D. Reichel, 1988, p. 208-217.

PINHEIRO, Maria Helena de Amorim. A Emergência do Ritual do Kiki no Contexto

Contemporâneo. Dissertação (Mestrado em Antropologia Social). Curitiba: Universidade Federal do Paraná, 2013.

ROSA, Rogério Reus Gonçalves da. Kaingang de Nonoai: A Chegada dos Brancos, a Transformação do Espaço e a Luta pelo Capão Alto (Perícia Antropológica). Porto Alegre: NIT-UFRGS, 2000.

"Os Kujà São Diferentes": Um estudo etnológico do complexo xamânico dos Kaingang da Terra Indígena Votouro. 2005. Tese (Doutorado em Antropologia). Porto Alegre: Universidade Federal do Rio Grande do Sul, Porto Alegre, [2005].

Mitologia e Xamanismo nas Relações Sociais dos Inuit e dos Kaingang.Espaço Ameríndio, Porto Alegre, v. 5, n. 3, p. 98-122, 2011.

.O Xamanismo Kaingang: a relação dos kujà com os espíritos animais/vegetais da floresta e os santos do panteão do catolicismo popular. In:Religiões e religiosidade 
no Rio Grande do Sul: manifestações da religiosidade indígena.São Paulo:ANPUH,2014a. p. 97-128.

.Os kujà são diferentes? Doenças invisíveis, aliança e guerra no xamanismo kaingang. Mediações, Londrina, v. 19, n. 2, p. 84-110, 2014 b.

SALADIN D'ANGLURE, Bernard. Mythe de la femme et pouvoir de l'homme chez les Inuit de l'Arctique central. Revue Anthropologie et Sociétés, Québec, v. 1, n. 3, p. 79 98, 1997.

Troisième Sexe Social, Atome Familial et Médiations Chamaniques: pour une anthropologie holiste. Anthropologie et Société, v. 31, n. 3, p. 165-184, 2007.

TOMASINI, Alfredo. La iniciación de los shamanes nivaklé (Chaco Boreal, Paraguay).Anthropos, n. 87, p. 63-82, 1992.

VON IHERING, Rodolpho. Dicionário dos Animais do Brasil. São Paulo: Editora Universidade de Brasília, 1968.

VYJKÁG, Adão Sales et al. Textos Kanhgág. Brasília: APBKG/Dka Áustria/MEC/PNUD, 1997.

\section{Vídeos}

CHAPECOZINHO (et alii). CD Kanhgág Jykre (Pensamento Kaingang). CD, 2002.

EMERICH, Karine. Documentário Kanhgág Ag Kãme (Histórias Kaingang). DVD, 2000 .

EMERICH, Karine; ROSA, Rogério Reus Gonçalves da. Documentário Kanhgág Kanhró (Sabedoria Kaingang). DVD, 2015.

VITORINO, Cassemiro; GOLDSCHMIDT, Ilka. Documentário Kiki - O Ritual da Resistência Kaingang. DVD, 2014.

Recebido em: $25 / 11 / 2017$ * Aprovado em: 29/12/2017* Publicado em: $31 / 12 / 2017$ 